\title{
'AP-4', a Medium Maturity, Large Seeded Peanut Variety with Resistance to Tomato Spotted Wilt ${ }^{1}$
}

\section{Barry L. Tillman and Daniel W. Gorbet ${ }^{2}$}

The 'AP-4' peanut variety was developed by the University of Florida, Institute of Food and Agricultural Sciences, North Florida Research and Education Center near Marianna, Florida. This variety was released in 2007 based on its competitive pod yield and excellent seed grade - total sound mature kernel percentage (TSMK).

AP-4 has demonstrated very good pod yield potential in Florida tests. Over three locations and three years (2006, 2007 and 2008), pod yield of AP-4 was greater than for 'Georgia Green', 'Georgia-03L', and 'AP-3'. (See Table 1.) The TSMK percentage of AP-4 was greater than that of AP-3, but similar to Georgia-03L and Georgia Green, which is known for excellent grade potential. (See Table 1.)

Additionally, AP-4 has good resistance to tomato spotted wilt virus (TSWV). Disease ratings of TSWV in AP-4 were similar to those of AP-3, which is known to have good resistance to TSWV. However, disease ratings of TSWV in AP-4 were less than those for Georgia Green or for Georgia-03L.

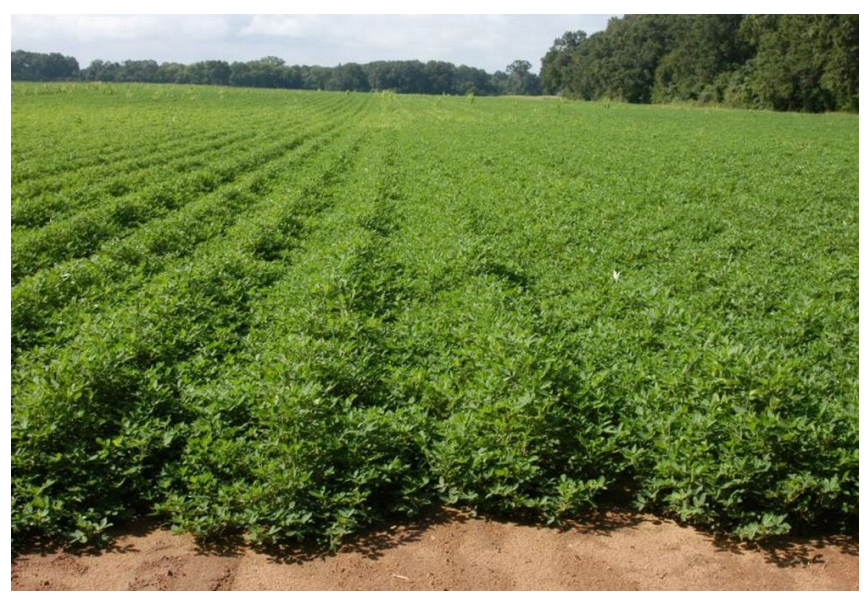

Figure 1. In this 2007 photo, 'AP-4' is pictured growing on the Florida's Foundation Seed Producers' Farm near the University of Florida`s North Florida Research and Education Center in Marianna, Fla. Credits: Tom Stadsclev, FFSP/IFAS/UF

In regards to resistance to white mold, AP-4 has moderate resistant while AP-3 is known to have very good resistance to white mold. Georgia Green is less resistant to white mold than are either AP-4 or AP-3. In two years of testing in Marianna, Florida, AP-4 lost an average of 44 percent of its pod yield in plots inoculated with $S$. rolfsii compared to AP-4 pod yield in plots not inoculated. In these trials AP-4's pod-yield loss was intermediate compared to the

1. This document is SS-AGR-324, one of a series of the Agronomy Department, Florida Cooperative Extension Service, Institute of Food and Agricultural Sciences, University of Florida. Original publication date, August 2009. Visit the EDIS Web site at http://edis.ifas.ufl.edu.

2. Barry L. Tillman, assistant professor, and Daniel W. Gorbet, retired professor, Agronomy Department, North Florida Research and Education Center--Marianna, FL, Institute of Food and Agricultural Sciences, University of Florida, Gainesville, FL.

The Institute of Food and Agricultural Sciences (IFAS) is an Equal Opportunity Institution authorized to provide research, educational information and other services only to individuals and institutions that function with non-discrimination with respect to race, creed, color, religion, age, disability, sex, sexual orientation, marital status, national origin, political opinions or affiliations. U.S. Department of Agriculture, Cooperative Extension Service, University of Florida, IFAS, Florida A. \& M. University Cooperative Extension Program, and Boards of County Commissioners Cooperating. Interim Dean Millie Ferrer. 
losses experienced by AP-3 (34 percent loss) and

Georgia Green (77 percent loss). However, AP-4's pod-yield loss was similar in these trials to losses in Georgia-03L (45 percent loss).

Plants of AP-4 have a prostrate growth habit with a semi-prominent main stem typical of runner cultivars. The testa of AP-4 seeds is tan in color. In Florida under irrigation, AP-4 requires approximately 135 days after planting to mature and is considered to have medium relative maturity.

The seed weight of AP-4 is larger than the historical runner market-type. The five-year average weight of 100 AP-4 seeds (70.3g) exceeds that of Georgia Green (56.9g) and AP-3 (63.5g), but is similar to Georgia-03L (71.5g), another large-seeded runner type. Large seed have implications for the proportion of various seed sizes from the grading process. Compared to the typical runner-type cultivar Georgia Green, AP-4 had fewer medium (37.9 percent vs. 46.1 percent) and more jumbo (29.6 percent vs. 18.3 percent) kernels in five years of testing.

Seed production of AP-4 is governed by the Plant Variety Protection Act (PVP); AP-4 seed can be produced and sold only as a class of certified seed and only by companies licensed by Florida Foundation Seed Producers, Inc. Birdsong Peanuts, Inc., Suffolk, Virginia, holds the exclusive license to produce and sell registered and certified classes of AP-4 seed. 
Table 1. Performance of Runner Market-Type Peanut Varieties in Two or Three Florida Locations over the Three-Year

Period -- 2006, 2007 and 2008. (Entries are sorted by maturity and the three-year average yield in descending order.)

\begin{tabular}{|c|c|c|c|c|c|c|c|c|c|c|}
\hline \multirow[b]{2}{*}{ Name } & \multirow[b]{2}{*}{ Maturity* } & \multicolumn{3}{|c|}{ Pod Yield (Ibs./A) } & \multicolumn{3}{|c|}{ TSMK \% (grade) } & \multicolumn{3}{|c|}{ TSWV /(1-10)*** } \\
\hline & & 2008 & 2-YR ${ }^{\dagger}$ & 3-YR ${ }^{\dagger \dagger}$ & 2008 & 2-YR & 3-YR & 2008 & 2-YR & 3-YR \\
\hline Andru II** & ME & 4265 & 4098 & 4076 & 73.5 & 74.2 & 74.7 & 2.1 & 3.6 & 3.4 \\
\hline Virugard & $\mathrm{ME}$ & 3965 & 3579 & 3878 & 77.4 & 77.9 & 77.3 & 2.8 & 4.4 & 4.1 \\
\hline Florida- $07^{\star \star}$ & $\mathrm{M}$ & 5563 & 5061 & 5127 & 76.1 & 76.2 & 76.8 & 1.9 & 2.0 & 2.1 \\
\hline Georgia-03L & $M$ & 4980 & 4177 & 4287 & 74.8 & 76.2 & 76.5 & 1.6 & 2.7 & 3.0 \\
\hline AT3085A** & $\mathrm{M}$ & 5087 & 4411 & 4489 & 75.7 & 75.6 & 75.7 & 1.2 & 2.9 & 2.9 \\
\hline AP-3 & $\mathrm{M}$ & 5023 & 4313 & 4336 & 74.6 & 74.9 & 74.5 & 1.4 & 2.4 & 2.4 \\
\hline McCloud $^{* *}$ & $M$ & 5145 & 4274 & 4248 & 76.9 & 77.4 & 76.7 & 1.3 & 2.4 & 2.6 \\
\hline AT3081R & $M$ & 5354 & 4345 & 4220 & 75.4 & 75.5 & 75.2 & 1.4 & 3.0 & 3.3 \\
\hline Carver & $\mathrm{M}$ & 5463 & 4447 & 4411 & 77.9 & 77.2 & 77.2 & 1.4 & 2.8 & 2.7 \\
\hline Georgia Green & $M$ & 4895 & 4228 & 4066 & 78.9 & 78.3 & 78.1 & 1.8 & 3.0 & 3.5 \\
\hline $\mathrm{AP}-4$ & $M$ & 5456 & 4907 & 4743 & 77.0 & 77.0 & 77.4 & 1.7 & 2.4 & 2.5 \\
\hline Georgia-06G & $\mathrm{M}$ & 5832 & 4893 & & 80.6 & 80.3 & & 1.8 & 2.6 & \\
\hline Georgia Greener & $\mathrm{M}$ & 5350 & 4862 & & 79.3 & 79.7 & & 1.9 & 2.4 & \\
\hline Georgia-07W & $\mathrm{M}$ & 5781 & & & 78.3 & & & 1.4 & & \\
\hline C-99R & $\mathrm{L}$ & 4870 & 4434 & 4423 & 77.7 & 78.1 & 77.1 & 1.8 & 2.6 & 2.6 \\
\hline Georgia-01R & $\mathrm{L}$ & 4296 & 4083 & 4383 & 78.9 & 79.1 & 79.0 & 1.3 & 1.8 & 1.9 \\
\hline York $^{* *}$ & $\mathrm{~L}$ & 4679 & 4261 & 4348 & 75.3 & 75.0 & 74.9 & 1.3 & 1.8 & 1.9 \\
\hline Georgia- $02 C^{* *}$ & $\mathrm{~L}$ & 4626 & 4205 & 4316 & 80.7 & 80.6 & 80.8 & 1.7 & 2.2 & 2.2 \\
\hline C.V. & & 12 & 15 & 14 & 2.1 & 1.9 & 2.4 & 38.0 & 36.5 & 33.3 \\
\hline LSD & & 479 & 505 & 354 & 1.9 & 1.2 & 1.3 & 0.5 & 0.6 & 0.4 \\
\hline \multicolumn{11}{|c|}{$\begin{array}{l}{ }^{*} E=\text { early; } M=\text { medium, and } L=\text { late. } \\
{ }^{* *} \text { High oleic oil chemistry. } \\
{ }^{* * *} \text { Tomato Spotted Wilt Virus ratings (1-10, } 1=\text { no disease). } \\
{ }^{\dagger} 2 \text { YR = average of } 2006 \text { and } 2007 . \\
{ }^{\dagger} 3 \text { YR = average of } 2006,2007 \text { and } 2008 .\end{array}$} \\
\hline
\end{tabular}

